\title{
Influence of substrate on strawberry plug plant production
}

\author{
By S. LÓPEZ-GALARZA* , A. SAN BAUTISTA, A. MARTÍNEZ, B. PASCUAL and \\ J. V. MAROTO
}

Departamento de Producción Vegetal, ETSIA, Universidad Politécnica de Valencia, Camino de Vera s/n, 46022 Valencia, Spain

(e-mail: slopez@prv.upv.es)

(Accepted 1 June 2010)

\section{SUMMARY}

The plug plant technique for the commercial propagation of strawberries is increasing in importance. Several factors, including the properties of the substrate, can affect plug plant quality. Tests on nine substrates containing different proportions of perlite [from $0-75 \%,(\mathrm{v} / \mathrm{v})$ ], and dark and light peat [both from $0-80 \%(\mathrm{v} / \mathrm{v})$ ], were performed using a simplex-lattice design in order to establish a model for strawberry plug plant production based not only on the single component composition of the substrate, but also on the influences of the chemical and physical properties of the substrate on plug plant quality. Notable differences in physical and chemical properties were found among the nine different substrates tested, as a consequence of the broad range of their component compositions. Substrate mixes containing medium-to-high proportions [from $60-70 \%(\mathrm{v} / \mathrm{v})$ ] of light peat and low proportions of dark peat and perlite are recommended, as these resulted in a low nutrient content, a high organic matter content, a low $\mathrm{pH}$, and a low "coarseness" index, which led to high-grade plug plants with greater root and crown dry weights.

$S^{c}$ eedling plants are commonly used for propagating most commercial vegetable crops. However, bare root plants are still commonly used as strawberry transplants. The plug plant technique for strawberries started in central Europe in the early 1980s (Lieten, 1998) and in the USA in the early 1990s (Poling and Parker, 1990). This technique has become more widespread due to generating higher profits compared with the use of bare root plants, especially after the banning of methyl bromide and despite its higher costs, which are a major restriction on the use of plug plants (Bish et al., 2002; Durner et al., 2002; Hochmuth et al., 2006). Among the reported benefits of plug plants are reduced soil-borne disease and, consequently, reduced pesticide application, easier planting, improved performance as "frigo" plants, increased savings in water through better water use efficiency (WUE), greater tolerance to planting stress, increased earliness, and higher yields (Durner et al., 2002).

Several factors can affect plug plant quality, including the characteristics of the plug (Poling and Parker, 1990; Bish et al., 2003), the irrigation system used and its management (Poling and Parker, 1990; Bish et al., 2001; 2003; Durner et al., 2002; Takeda et al., 2004), plant nutrition, cell-size and cell-geometry (Mohamed, 1998; Bish et al., 2001; 2003; Takeda and Hokanson, 2002; Palha et al., 2002; Robbe, 2004), substrate properties, and the nutrition schedule, among others.

Previous reports have not found any clear differences in strawberry plant behaviour in relation to different types of substrate. However, considerable differences have been reported in other potted seedling species. Paranjpe et al. (2003) indicated that the substrate used for strawberry should be selected taking into account cost and availability.

*Author for correspondence.
In some cases, only inorganic substrates (i.e., perlite and vermiculite) were used in different proportions (Bish et al., 2001; 2003; Paranjpe et al., 2003), but the most common substrates are peat mixes (Castillo and Arjona, 2004), or mixes of organic and inorganic substrates (Poling and Parker, 1990; Mohamed, 1998; Crawford et al., 2000; Paranjpe et al., 2003; Robbe, 2004). In addition, fertilisers, root growth enhancers, hydrogels, and rhizobacteria (Kokalis-Burelle, 2003) may be added to increase seedling growth and to improve plug quality.

In the present study, our objective was to determine a model for producing strawberry plug plants based not only on the single component composition of the substrate, but also on the influence of the chemical and physical properties of the substrate on plug plant quality, in order to choose the most appropriate single components, considering their availability and price.

\section{MATERIALS AND METHODS}

The experiment was carried out in Summer 2007, in a greenhouse at the Universidad Politécnica de Valencia. Nine substrates (Table I) were generated by mixing different (v/v) proportions of perlite (Pe; Floreal ${ }^{\circledR}$ F-13, Semillas Diago, Valencia, Spain), light Sphagnum peat [LP; degree of decomposition H2-H5, according to the Von Post-scale (Von Post, 1937); Vriezenveen ${ }^{\circledR}$, Free Peat B.V., Vriezenveen, The Netherlands], and dark Sphagnum peat (DP; H5-H6; Vriezenveen ${ }^{\circledR}$, Free Peat B.V.) and tested using a $\{3,2\}$ simplex-lattice design (Cornell, 1990).

Runner tips of the strawberry (Fragaria $\times$ ananassa Duch.) cultivar 'Camarosa' were plugged in polyethylene trays each containing 35 truncatedpyramidal cells $(50 \mathrm{~mm} \times 50 \mathrm{~mm} \times 115 \mathrm{~mm}$; total 
volume $=200 \mathrm{ml}$ ). Runner tips with their first leaf still unfolded, with a runner diameter of approx. 3-4 mm were selected from uniform mother plants grown specifically for this purpose. Plugging took place on 13 August 2007.

Irrigation during the first $5 \mathrm{~d}$ was achieved by microsprinklers $\left(0.7 \mathrm{l} \mathrm{m}^{-2} \mathrm{~d}^{-1}\right)$, then by sub-irrigation. Only water was applied during the first week, then a nutrient solution containing (in mmol ${ }^{-1}$ ): $12.4 \mathrm{NO}_{3}^{-} ; 1.2 \mathrm{H}_{2} \mathrm{PO}_{4}^{-}$; $2.5 \mathrm{SO}_{4}^{2-} ; 0.5 \mathrm{NH}_{4}^{+} ; 5.0 \mathrm{~K}^{+} ; 4.1 \mathrm{Ca}^{2+}$; and $3.0 \mathrm{Mg}^{2+}$. A shading screen was extended when the solar radiation exceeded $600 \mathrm{~J} \mathrm{~m}^{-2} \mathrm{~s}^{-1}$.

The 27 trays of the experiment (three trays per treatment) were arranged at random on the benches of the greenhouse. Only those plugs in the 15 cells in the central part of each tray were evaluated, in order to avoid border effects.

On 29 September 2007 (44 d after plugging) when each plant had two new, fully-expanded leaves, two independent experts evaluated plug transplant quality (plug grade) by measuring the volume of substrate filled by the root system, using a visual scale from 0 to 10 , where 5 indicated that the transplant was extracted from the plug tray with its shape intact, but the substrate was not entirely filled with roots. Higher or lower values indicated higher or lower transplant compactness, a characteristic related directly to root development. The primary roots were separated to measure their fresh weights (FWs) and dry weights (DWs). Petiole lengths, the numbers of leaves, and the FWs and DWs of the leaves and crowns were also measured. Dry weights were obtained after $72 \mathrm{~h}$ drying in an oven at $65^{\circ} \mathrm{C}$.

Physical parameters such as coarseness index [CI; a parameter that defines the particle size-distribution as a single value, calculated and expressed as the cumulative percentage (by weight) for all particles with a diameter $>1 \mathrm{~mm}$ (i.e., the sum of those fractions with particle sizes ranging from $>1 \mathrm{~mm}$ to $>16 \mathrm{~mm}$ ); adapted from Richards et al., 1986], bulk density (BD), particle density (PD), total porosity (TP), air volume (AV), and water volume (WV) were determined following European Standards (EN 13041, 2001). Electrical conductivity (EC) and $\mathrm{pH}$ were determined in a suspension $(\mathrm{pH})$ or extract (EC) of each substrate using the 1:5 (v/v) water extraction procedure (EN 13037, 2001; EN 13038, 2001).

The available mineral element concentrations of each substrate were determined following EN 13040, 2001). Nitrate $\left(\mathrm{NO}_{3}^{-}\right)-\mathrm{N}$ levels were determined by ionic chromatography (Model $2000 \mathrm{i} / \mathrm{sp}^{\circledR}$; Dionex, Sunnyvale, CA, USA), and ammonium $\left(\mathrm{NH}_{4}^{+}\right)-\mathrm{N}$ levels by flow injection analysis (FIA; Raigón et al., 1992). Phosphorus,

TABLE I

Percentage compositions of perlite, dark peat, and light peat in each substrate used

\begin{tabular}{lccc}
\hline Substrate & Perlite $(\%)$ & Dark peat $(\%)$ & Light peat $(\%)$ \\
\hline S1 & 0 & 20 & 80 \\
S2 & 0 & 50 & 50 \\
S3 & 0 & 80 & 20 \\
S4 & 25 & 15 & 60 \\
S5 & 25 & 60 & 15 \\
S6 & 50 & 10 & 40 \\
S7 & 50 & 40 & 10 \\
S8 & 75 & 20 & 5 \\
S9 & 33 & 33 & 33 \\
\hline
\end{tabular}

potassium, calcium, magnesium, sulphate, and sodium ions were analysed by Inductively Coupled Plasma Atomic Emission Spectrometry (ICP-AES; Spectroflame ${ }^{\circledR}$ Model ICP-D; Spectro, Kleve, Germany). Chloride ion contents were determined using an automatic titrator (Radiometer Model CMT10; Swissteco Instruments, Eichenwies, Switzerland). Total organic matter (OM) contents were determined using the European Standards procedure (EN 13039, 2001). All physical, physico-chemical, and chemical determinations were carried out in triplicate.

The significance of the differences was assessed by analysis of variance (ANOVA). Percentage data were arcsin transformed before analysis. $P$ values $<0.05$ were considered significant. Mean separation was done using the LSD test at $P<0.05$. A multiple regression analysis was done to adjust some parameters to the canonical second degree expression:

$$
\begin{aligned}
& Y=\beta 1 * \mathrm{Pe}+\beta 2 * \mathrm{DP}+\beta 3 * \mathrm{LP}+\beta 4 * \mathrm{Pe} * \mathrm{DP}+\beta 5 * \mathrm{Pe} * \mathrm{LP} \\
& +\beta 6 * \mathrm{DP} * \mathrm{LP}
\end{aligned}
$$

where $Y$ was the parameter; Pe, DP, and LP were the proportions $[\%(\mathrm{v} / \mathrm{v})]$ of perlite, dark peat, and light peat respectively; and $\beta 1 \ldots \beta 6$, were the co-efficients for each variable and their two-way interactions. The results of the regressions were drawn in triangular space using Matlab ${ }^{\circledR}$ Version 6.1 software (MathWorks, Natick, MA, USA).

\section{RESULTS AND DISCUSSION}

\section{Substrate characterisation}

Notable differences in physical and chemical properties were found among the nine substrates tested, as expected from the broad range of proportions of the different components used.

Substrates S1 (0-20-80), S2 (0-50-50), and S3 (0-80-20), having only organic constituents, had the highest levels of organic matter and higher water volumes, since Sphagnum peat is characterised by having a high waterholding capacity as it contains many phenolic and hydroxylic radicals (Raviv et al., 2002). In contrast, substrates S6 (50-10-40), S7 (50-40-10), and S8 (75-20-5), having higher proportions of perlite, had lower organic matter contents, retained less water, and had higher air contents.

Coarseness index (CI) was higher in those substrates with the highest proportions of perlite: namely, S6 (5010-40), S7 (50-40-10), and S8 (75-20-5). Similar trends were found for particle density.

Bulk density (BD) was highest in substrates S3 (0-80$20)$ and S5 (25-60-15), and lowest in S1 (0-20-80), S4 (2515-60), and S6 (50-10-40) which contained low proportions of dark peat (Table II), in agreement with the results of Maher et al. (2008). The highest TP values were measured in S6 (50-10-40) and S8 (75-20-5), and the lowest in S2 (0-50-50) and S5 (25-60-15).

Substrates S3 (0-80-20), S5 (25-60-15), and S7 (50-4010) had high proportions of both dark and light peat, and therefore the lowest pH (Table III). Electrical conductivity (EC) was higher in those substrates containing the highest proportions of dark peat [i.e., S3 (0-80-20) and S5 (25-60-15); Table III]. These substrates also had the highest levels of $\mathrm{NO}_{3}^{-}, \mathrm{H}_{2} \mathrm{PO}_{4}^{-}, \mathrm{SO}_{4}{ }^{2-}, \mathrm{K}^{+}$, 
TABLE II

Physical parameters of the nine substrates tested and mean separations

\begin{tabular}{|c|c|c|c|c|c|c|}
\hline Substrate $[(v / v / v)$ Pe-DP-LP] & $\begin{array}{c}\text { Coarseness } \\
\text { index }(\%)\end{array}$ & $\begin{array}{c}\text { Bulk } \\
\text { density }\left(\mathrm{kg} \mathrm{m}^{-3}\right)\end{array}$ & $\begin{array}{c}\text { Particle } \\
\text { density }\left(\mathrm{kg} \mathrm{m}^{-3}\right)\end{array}$ & $\begin{array}{c}\text { Total } \\
\text { porosity }(\%)\end{array}$ & $\begin{array}{c}\text { Air } \\
\text { volume }(\%)\end{array}$ & $\begin{array}{c}\text { Water } \\
\text { volume (\%) }\end{array}$ \\
\hline S1 (0-20-80) & $36 \mathrm{f}^{\dagger}$ & $115 \mathrm{~g}$ & $1,515 \mathrm{e}$ & $92.4 \mathrm{bc}$ & $18.8 \mathrm{e}$ & $73.6 \mathrm{~b}$ \\
\hline $\mathrm{S} 2(0-50-50)$ & $32 \mathrm{~g}$ & $137 \mathrm{de}$ & $1,509 \mathrm{e}$ & $90.9 \mathrm{~d}$ & $13.3 \mathrm{f}$ & $77.6 \mathrm{a}$ \\
\hline S3 $(0-80-20)$ & $34 \mathrm{~g}$ & $153 \mathrm{a}$ & $1,506 \mathrm{e}$ & $89.8 \mathrm{e}$ & $12.3 \mathrm{f}$ & $77.5 \mathrm{a}$ \\
\hline S4 $(25-15-60)$ & $50 \mathrm{~d}$ & $127 \mathrm{f}$ & $1,750 \mathrm{c}$ & $92.7 \mathrm{~b}$ & $30.2 \mathrm{~d}$ & $62.5 \mathrm{c}$ \\
\hline S5 $(25-60-15)$ & $46 \mathrm{e}$ & $151 \mathrm{ab}$ & $1,695 \mathrm{~d}$ & $91.1 \mathrm{~d}$ & $19.7 \mathrm{e}$ & $71.4 \mathrm{~b}$ \\
\hline S6 (50-10-40) & $62 \mathrm{~b}$ & 129 ef & $1,977 \mathrm{~b}$ & $93.5 \mathrm{a}$ & $46.6 \mathrm{~b}$ & $46.9 \mathrm{e}$ \\
\hline S7 $(50-40-10)$ & $54 \mathrm{c}$ & $149 \mathrm{abc}$ & $1,948 \mathrm{~b}$ & $92.4 \mathrm{bc}$ & $35.2 \mathrm{c}$ & $57.2 \mathrm{~d}$ \\
\hline S8 $(75-20-5)$ & $71 \mathrm{a}$ & $141 \mathrm{~cd}$ & $2,187 \mathrm{a}$ & $93.6 \mathrm{a}$ & $56.1 \mathrm{a}$ & $37.5 \mathrm{f}$ \\
\hline S9 $(33-33-33)$ & $46 \mathrm{e}$ & $143 \mathrm{bcd}$ & $1,759 \mathrm{c}$ & $91.9 \mathrm{c}$ & $21.3 \mathrm{e}$ & $70.6 \mathrm{~b}$ \\
\hline ANOVA (degrees of freedom) & \multicolumn{6}{|c|}{$\%$ Total sum of squares } \\
\hline Substrates (8) & $99.50 * *$ & $86.97 * *$ & $99.41 * *$ & $93.24 * *$ & $99.09 * *$ & $98.86 * *$ \\
\hline Error (18) & 0.50 & 13.03 & 0.59 & 6.76 & 0.91 & 1.14 \\
\hline Standard deviation & 1.05 & 0.00 & 0.02 & 0.38 & 1.68 & 1.76 \\
\hline
\end{tabular}

** Indicates significant differences at $P<0.01$.

Standard deviation was obtained as the root-square of the average square of the error.

${ }^{\dagger}$ Mean values followed by different lower-case letters in each column indicate significant differences at $P<0.05$ using the LSD test.

$\mathrm{Ca}^{2+}$, and $\mathrm{Mg}^{2+}$. These results agree with those reported for the chemical characteristics of different types of peat by Raviv et al. (2002). The lowest levels of all these ions were found in the substrates S1 (0-20-80), S4 (25-15-60), and S6 (50-10-40), which had the lowest proportions of dark peat (Table III). Differences in the levels of $\mathrm{NH}_{4}{ }^{+}$, $\mathrm{Cl}^{-}$, and $\mathrm{Na}^{+}$ions among the nine substrates were not statistically significant.

Results from the physical characterisation of each substrate coincided, in general, with the expected results. Dark peat, with the highest bulk density, was the substrate with the largest content of fine particles and, as a consequence, with the highest water content, the lowest total porosity, and the lowest total air volume. In addition, we found that the higher the proportion of perlite, the higher the substrate porosity and air volume and, by contrast, the lower the water volume. Therefore, better drainage and lower water retention were obtained using substrate mixes with a high proportion of perlite, as indicated by Bunt (1988).

In relation to chemical properties, the higher the proportion in DP, the higher the EC, the greater the level of $\mathrm{NO}_{3}^{-}-\mathrm{N}$, and, in general, the higher the concentration of other ions, as is well known for this kind of peat.

\section{Plant growth parameters}

Plant survival at the end of the experiment was $90 \%$, on average. No significant differences in plant survival were found among the nine substrates tested (Table IV). Paranjpe et al. (2004) obtained similar results for plant survival using other substrate mixes, which indicates that substrate composition does not restrict strawberry plant survival during the plug production cycle.

The visual plug grades of the transplants were highest in S4 (25-15-60; Table IV). This substrate can thus be considered to be the best balanced, taking into account its physical and chemical properties. S4 (25-15-60) had an intermediate organic matter content $(62.1 \%)$, a high TP (92.7\%), a low-to-medium air volume $(30.2 \%)$, and a medium-to-high water content (62.5\%; Table II). However, substrate S2, without perlite and equal parts of DP and LP, did not differ significantly from S4 in plug grade, despite having a higher organic matter content, a higher water content, and a lower air volume than S4. In general, higher proportions of perlite led to lesscompacted plugs, resulting in the substrate falling-off the roots when the plug was extracted from the tray. For a commercial strawberry plug system, Durner et al. (2002) recommended mixes with air volume and water contents of approx. $5 \%$ and $75 \%$, respectively; closer to those of S2. Paranjpe et al. (2004) reported similar values for plug transplant quality, and the highest values were obtained using substrates without perlite.

The largest numbers of leaves were obtained with S3 (0-80-20) and S8 (75-20-5), while the lowest numbers were with S4 (25-15-60), S5 (25-60-15), and S9 (33-33-33;

TABLE III

Physico-chemical and chemical parameters of the nine substrates and mean separations

\begin{tabular}{|c|c|c|c|c|c|c|c|c|c|c|c|c|}
\hline $\begin{array}{l}\text { Substrates } \\
{[(\mathrm{v} / \mathrm{v} / \mathrm{v}) \mathrm{Pe}-\mathrm{DP}-\mathrm{LP}]}\end{array}$ & $\mathrm{pH}$ & $\begin{array}{c}\mathrm{EC}^{\S} \\
\left(\mathrm{mS} \mathrm{m}^{-1}\right)\end{array}$ & $\begin{array}{l}\mathrm{OM} \\
(\%)\end{array}$ & $\begin{array}{l}\mathrm{N}-\mathrm{NO}_{3}^{-} \\
\left(\mathrm{mg} \mathrm{l}^{-1}\right)\end{array}$ & $\begin{array}{l}\mathrm{N}-\mathrm{NH}_{4}^{+} \\
\left(\mathrm{mg} \mathrm{l}^{-1}\right)\end{array}$ & $\begin{array}{l}\mathrm{H}_{2} \mathrm{PO}_{4}^{-} \\
\left(\mathrm{mg} \mathrm{l}^{-1}\right)\end{array}$ & $\begin{array}{c}\mathrm{K}^{+} \\
\left(\mathrm{mg} \mathrm{l}^{-1}\right)\end{array}$ & $\begin{array}{c}\mathrm{Ca}^{2+} \\
\left(\mathrm{mg} \mathrm{l}^{-1}\right)\end{array}$ & $\begin{array}{c}\mathrm{Mg}^{2+} \\
\left(\mathrm{mg} \mathrm{l}^{-1}\right)\end{array}$ & $\begin{array}{c}\mathrm{Cl}^{-} \\
\left(\mathrm{mg} \mathrm{l}^{-1}\right)\end{array}$ & $\begin{array}{c}\mathrm{SO}_{4}{ }^{2-} \\
\left(\mathrm{mg} \mathrm{l}^{-1}\right)\end{array}$ & $\begin{array}{c}\mathrm{Na}^{+} \\
\left(\mathrm{mg} \mathrm{l}^{-1}\right)\end{array}$ \\
\hline S1 (0-20-80) & $6.15 \mathrm{~b}^{\dagger}$ & $51.33 \mathrm{f}$ & $90.51 \mathrm{a}$ & $0.02 \mathrm{e}$ & $0.0006 \mathrm{~d}$ & $0.71 \mathrm{e}$ & $0.80 \mathrm{~d}$ & $0.54 \mathrm{~d}$ & $0.16 \mathrm{f}$ & $0.95 a$ & $1.34 \mathrm{~cd}$ & $0.68 \mathrm{c}$ \\
\hline S2 (0-50-50) & $5.88 \mathrm{c}$ & $186.33 \mathrm{c}$ & $91.37 \mathrm{a}$ & $2.66 \mathrm{~b}$ & $0.0056 \mathrm{ab}$ & $1.64 \mathrm{c}$ & $2.11 \mathrm{~b}$ & $3.15 \mathrm{~b}$ & $0.99 \mathrm{c}$ & $0.94 \mathrm{a}$ & $3.83 \mathrm{~b}$ & $0.97 \mathrm{ab}$ \\
\hline S3 $(0-80-20)$ & $5.60 \mathrm{de}$ & $262.67 \mathrm{a}$ & $91.82 \mathrm{a}$ & $4.17 \mathrm{a}$ & $0.0070 \mathrm{ab}$ & $2.48 \mathrm{a}$ & $2.70 \mathrm{a}$ & $4.90 \mathrm{a}$ & $1.72 \mathrm{a}$ & $0.81 \mathrm{ab}$ & $5.67 \mathrm{a}$ & $1.00 \mathrm{a}$ \\
\hline$-15-60)$ & $6.20 \mathrm{~b}$ & $47.33 \mathrm{f}$ & $62.14 \mathrm{c}$ & $0.13 \mathrm{e}$ & $0.0057 \mathrm{ab}$ & 0.55 ef & $0.79 \mathrm{~d}$ & $0.50 \mathrm{~d}$ & 0.1 & $0.57 \mathrm{~cd}$ & $0.97 \mathrm{~d}$ & $0.60 \mathrm{c}$ \\
\hline$-60-15)$ & $5.67 \mathrm{~d}$ & $239.00 \mathrm{~b}$ & $68.08 \mathrm{~b}$ & $3.95 \mathrm{a}$ & $0.0076 \mathrm{a}$ & $2.13 \mathrm{~b}$ & $2.39 \mathrm{ab}$ & $4.45 \mathrm{a}$ & $1.54 \mathrm{~b}$ & $0.71 \mathrm{bc}$ & $5.16 \mathrm{a}$ & $1.12 \mathrm{a}$ \\
\hline$-10-40)$ & $6.40 \mathrm{a}$ & $40.67 \mathrm{f}$ & $41.16 \mathrm{~d}$ & $0.11 \mathrm{e}$ & $0.0020 \mathrm{~cd}$ & $0.39 \mathrm{f}$ & $0.50 \mathrm{~d}$ & $0.41 \mathrm{~d}$ & $0.13 \mathrm{f}$ & $0.57 \mathrm{~cd}$ & $1.18 \mathrm{~d}$ & $0.76 \mathrm{bc}$ \\
\hline$-40-10)$ & $5.45 \mathrm{e}$ & $177.33 \mathrm{~cd}$ & $43.51 \mathrm{~d}$ & $2.63 \mathrm{~b}$ & $0.0046 \mathrm{bc}$ & $1.26 \mathrm{~d}$ & $1.51 \mathrm{c}$ & $3.01 \mathrm{~b}$ & $1.06 \mathrm{c}$ & $0.52 \mathrm{~cd}$ & $3.61 \mathrm{~b}$ & $0.95 \mathrm{ab}$ \\
\hline S8 & $6.00 \mathrm{bc}$ & $107.00 \mathrm{e}$ & $25.60 \mathrm{e}$ & $1.45 \mathrm{~d}$ & $0.0063 \mathrm{ab}$ & 0.59 ef & $0.61 \mathrm{~d}$ & $1.44 \mathrm{~d}$ & $0.55 \mathrm{e}$ & $0.43 \mathrm{~d}$ & $2.26 \mathrm{c}$ & $1.15 \mathrm{a}$ \\
\hline 33-33) & $5.92 \mathrm{c}$ & $159.67 \mathrm{~d}$ & $61.24 \mathrm{c}$ & $2.13 \mathrm{c}$ & $0.0047 \mathrm{bc}$ & $1.11 \mathrm{~d}$ & $1.51 \mathrm{c}$ & $2.35 \mathrm{c}$ & $0.80 \mathrm{~d}$ & $0.88 \mathrm{ab}$ & $2.32 \mathrm{c}$ & $1.05 \mathrm{a}$ \\
\hline \multicolumn{13}{|c|}{ ANOVA (degrees of freedom) } \\
\hline Substrates (8) & $90.17 * *$ & $98.29 * *$ & $99.56 * *$ & $98.14 * *$ & $69.60 * *$ & $97.58 * *$ & $96.07 * *$ & $97.13 * *$ & $98.22 * *$ & $76.36 * *$ & $91.16^{* *}$ & $75.03 * *$ \\
\hline Error (18) & 9.83 & 1.71 & 0.44 & 1.86 & 30.40 & 2.42 & 3.93 & 2.87 & 1.78 & 23.64 & 8.84 & 24.97 \\
\hline Standard deviation ${ }^{\frac{7}{*}}$ & 0.12 & 0.13 & 1.86 & 0.25 & 0.0017 & 0.13 & 0.19 & 0.34 & 0.09 & 0.12 & 0.62 & 0.13 \\
\hline
\end{tabular}

**Indicates significant differences at $P<0.01$.

Standard deviation was obtained as the root-square of the average square of the error.

${ }^{\dagger}$ Mean values followed by different lower-case letters in each column indicate significant differences at $P<0.05$ using the LSD test.

${ }^{\S} \mathrm{EC}$, electrical conductivity; OM, organic matter. 


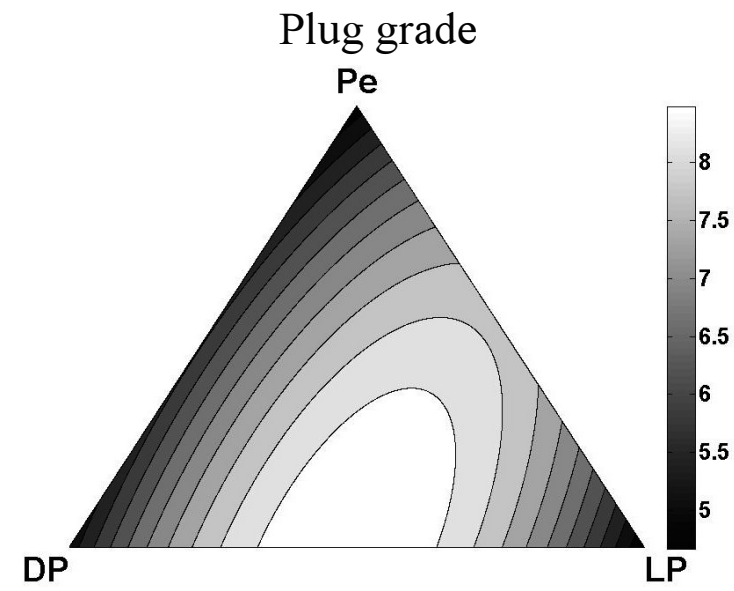

$Y=4.809^{* *} \mathrm{Pe}+5.187^{* *} \mathrm{DP}+4.187^{*} \mathrm{LP}+$

+3.010 Pe $\times \mathrm{DP}+12.899^{* *} \mathrm{Pe} \times \mathrm{LP}+15.731 \mathrm{DP} \times \mathrm{LP}$ $R^{2}=0.984^{* *}$

Leaf number

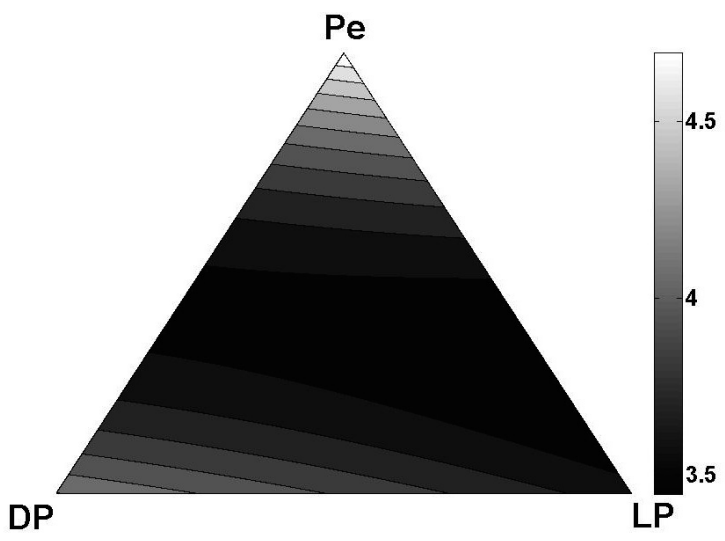

$Y=4.821^{* *} \mathrm{Pe}+4.197^{* *} \mathrm{DP}+3.624^{* *} \mathrm{LP}-$

$-3.801^{* *} \mathrm{Pe} \times \mathrm{DP}-2.547^{*} \mathrm{Pe} \times \mathrm{LP}+0.058 \mathrm{DP} \times \mathrm{LP}$ $R^{2}=0.997^{\text {** }}$

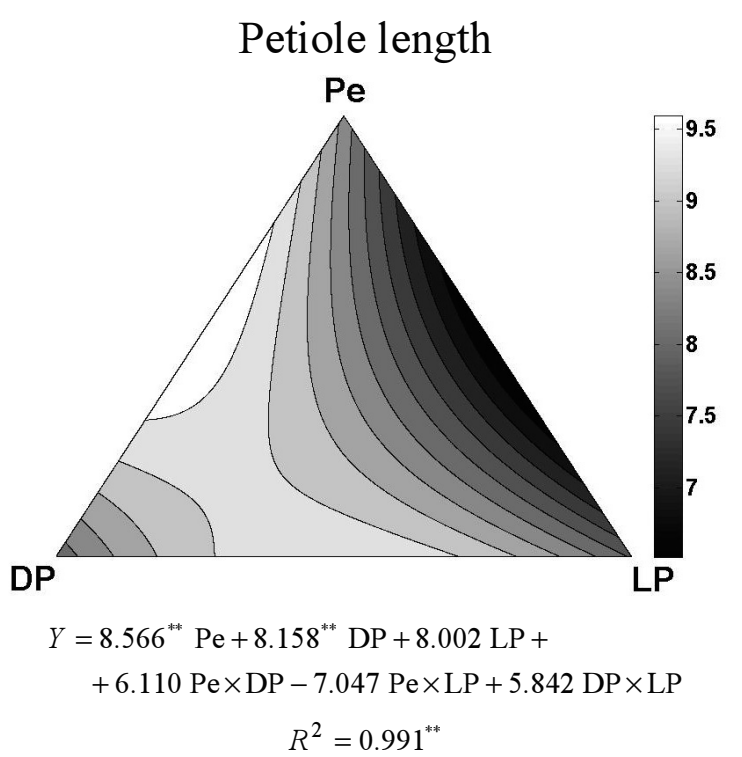

Root dry weight

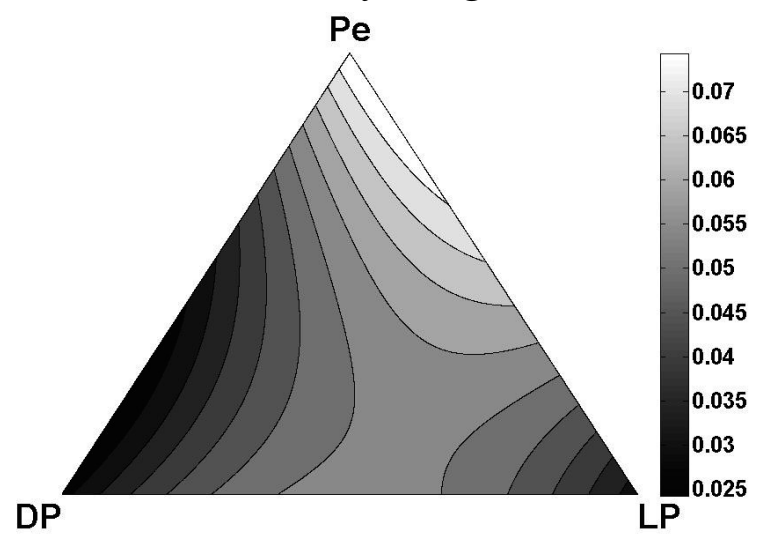

$Y=0.079^{* *} \mathrm{Pe}+0.027 \mathrm{DP}+0.031 \mathrm{LP}$ -

$-0.084 \mathrm{Pe} \times \mathrm{DP}+0.052 \mathrm{Pe} \times \mathrm{LP}+0.109 \mathrm{DP} \times \mathrm{LP}$ $R^{2}=0.968^{* *}$

Leaf dry weight

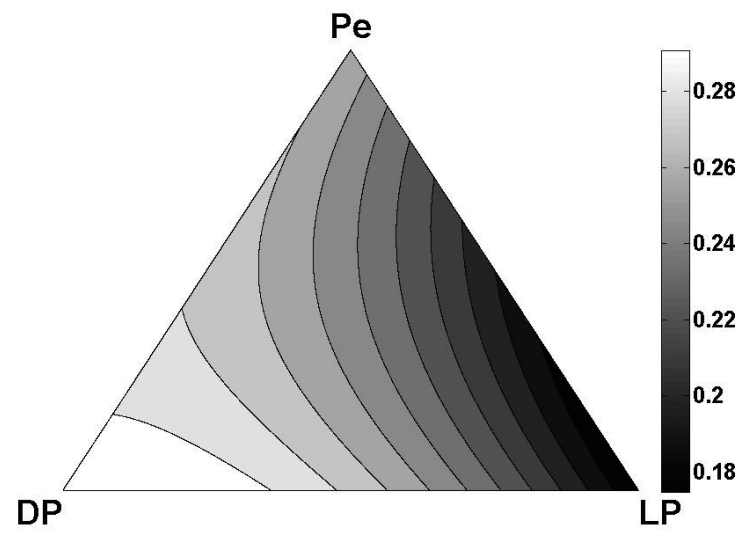

$Y=0.266^{* *} \mathrm{Pe}+0.301^{* *} \mathrm{DP}+0.175^{* *} \mathrm{LP}-$

$-0.031 \mathrm{Pe} \times \mathrm{DP}-0.089 \mathrm{Pe} \times \mathrm{LP}+0.153 \mathrm{DP} \times \mathrm{LP}$ $R^{2}=0.988^{* *}$

Crown dry weight

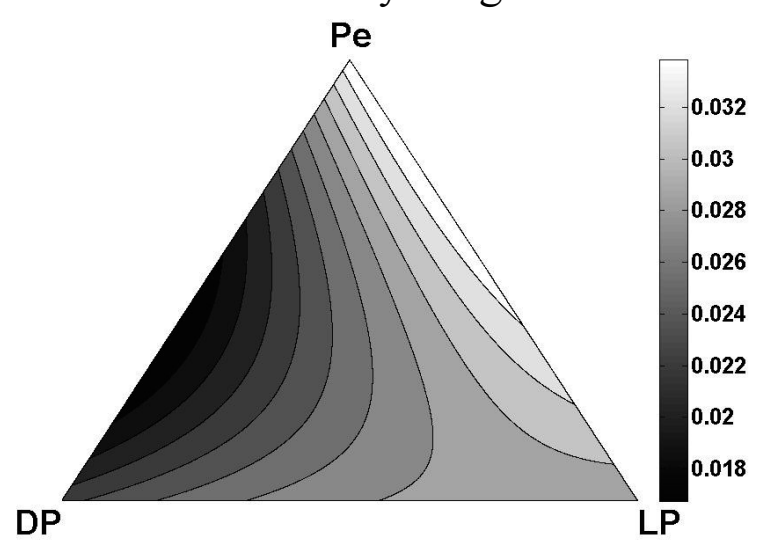

$Y=0.035^{* *} \mathrm{Pe}+0.023^{* *} \mathrm{DP}+0.029^{* *} \mathrm{LP}-$

$-0.046^{*} \mathrm{Pe} \times \mathrm{DP}+0.009 \mathrm{Pe} \times \mathrm{LP}+0.009 \mathrm{DP} \times \mathrm{LP}$

$$
R^{2}=0.986^{* *}
$$

FIG. 1

Regression analysis for six vegetative parameters (plug grade, root DW, leaf number, leaf DW, petiole length, and crown DW) of strawberry plug plants grown in nine different substrates S1 - S9 (Table I). Plots and fitted second-degree expressions and significance of the model are shown. The symbols * or ** indicate significances at $P<0.05$ or $P<0.01$, respectively, for both the model and the co-efficients. 
TABLE IV

Vegetative parameters of strawberry plug plants grown in each of the nine substrates evaluated, and mean separations

\begin{tabular}{|c|c|c|c|c|c|c|c|}
\hline \multirow[b]{2}{*}{$\begin{array}{l}\text { Substrate } \\
{[(\mathrm{v} / \mathrm{v} / \mathrm{v}) \text { Pe-DP-LP] }}\end{array}$} & \multirow[b]{2}{*}{$\begin{array}{l}\text { Survival } \\
(\%)\end{array}$} & \multirow[b]{2}{*}{$\begin{array}{l}\text { Plug grade } \\
(0-10)\end{array}$} & \multirow[b]{2}{*}{$\begin{array}{l}\text { No. of } \\
\text { leaves }\end{array}$} & \multirow[b]{2}{*}{$\begin{array}{c}\text { Petiole } \\
\text { length }(\mathrm{cm})\end{array}$} & \multicolumn{3}{|c|}{ Dry weight } \\
\hline & & & & & $\begin{array}{c}\text { Roots } \\
\left(\mathrm{g} \text { plant }^{-1}\right)\end{array}$ & $\begin{array}{l}\text { Leaves } \\
\left(\mathrm{g} \text { plant }^{-1}\right)\end{array}$ & $\begin{array}{c}\text { Crown } \\
\left(\text { g plant }^{-1}\right)\end{array}$ \\
\hline S1 (0-20-80) & 93.3 & $6.8 \mathrm{c}^{\dagger}$ & $3.8 \mathrm{abc}$ & $9.3 \mathrm{a}$ & 0.05 & 0.24 cde & $0.03 \mathrm{a}$ \\
\hline S2 $(0-50-50)$ & 98.0 & $9.2 \mathrm{ab}$ & $3.9 \mathrm{ab}$ & $9.1 \mathrm{a}$ & 0.06 & $0.26 \mathrm{abcd}$ & $0.03 \mathrm{a}$ \\
\hline S3 (0-80-20) & 84.7 & $7.4 \mathrm{c}$ & $4.1 \mathrm{a}$ & $9.2 \mathrm{a}$ & 0.05 & $0.30 \mathrm{a}$ & $0.03 \mathrm{a}$ \\
\hline S4 (25-15-60) & 91.3 & $9.4 \mathrm{a}$ & $3.4 \mathrm{c}$ & $7.2 \mathrm{~b}$ & 0.06 & $0.19 \mathrm{e}$ & $0.03 \mathrm{a}$ \\
\hline S5 (25-60-15) & 88.7 & $7.6 \mathrm{bc}$ & $3.5 \mathrm{c}$ & $9.3 \mathrm{a}$ & 0.04 & $0.28 \mathrm{ab}$ & $0.02 \mathrm{~b}$ \\
\hline S6 (50-10-40) & 98.0 & $7.6 \mathrm{bc}$ & $3.6 \mathrm{bc}$ & $7.5 \mathrm{~b}$ & 0.06 & $0.22 \mathrm{de}$ & $0.03 \mathrm{a}$ \\
\hline S7 (50-40-10) & 98.0 & $6.8 \mathrm{c}$ & $3.7 \mathrm{bc}$ & $9.0 \mathrm{a}$ & 0.05 & $0.24 \mathrm{bcd}$ & $0.02 \mathrm{~b}$ \\
\hline S8 (75-20-5) & 93.3 & $6.2 \mathrm{c}$ & $3.9 \mathrm{ab}$ & $9.2 \mathrm{a}$ & 0.06 & $0.27 \mathrm{abc}$ & $0.03 \mathrm{a}$ \\
\hline S9 (33-33-33) & 98.0 & $7.4 \mathrm{c}$ & $3.5 \mathrm{c}$ & $9.7 \mathrm{a}$ & 0.05 & $0.29 \mathrm{ab}$ & $0.03 \mathrm{a}$ \\
\hline \multicolumn{4}{|c|}{ ANOVA (degrees of freedom) } & \multicolumn{4}{|c|}{$\%$ Total sum of squares } \\
\hline Substrates (8) & $39.7 \mathrm{~ns}$ & $62.7 * *$ & $60.1 *$ & $58.4 *$ & $41.8 \mathrm{~ns}$ & $69.2 * *$ & $66.7 * *$ \\
\hline Error (18) & 60.3 & 37.3 & 39.9 & 41.6 & 58.2 & 30.8 & 33.3 \\
\hline Standard deviation ${ }^{*}$ & 1.02 & 0.96 & 0.23 & 0.86 & 0.01 & 0.03 & 0.003 \\
\hline
\end{tabular}

*** Significant differences at $P<0.05$ and $P<0.01$, respectively. ns, not significant.

${ }^{\ddagger}$ Standard deviation was obtained as the root-square of the average square of the error

${ }^{\dagger}$ Mean values followed by different lower-case letters in each column indicate significant differences at $P<0.05$ using the LSD test.

Table IV). The shortest petioles were obtained with S4 (25-15-60) and S6 (50-10-40; Table IV).

Differences in the DWs of roots were not significant among the nine substrates (Table IV), but the DWs of the leaf blades were highest in S3 (0-80-20) and lowest in S4 (25-15-60) and in S6 (50-10-40; Table IV). Crown DWs were significantly lower in S5 (25-60-15) and in S7 (5040-10; Table IV).

\section{Regression analysis}

The predicted responses from regression analysis for the vegetative parameters are presented in Figure 1. The mathematical models were highly significant $(P<0.01)$ and had high values of $R^{2}$. The model that fitted these parameters explained most of the total variation (Figure $1)$. The proportions of Pe, DP, and LP in the nine substrates had a strong positive influence on all vegetative parameters. As indicated by the model, the three components interacted synergistically and antagonistically with each other in regard to these parameters. For some vegetative parameters, the interactions were significant $(P<0.01 ; P<0.05)$.

The mathematical model indicated that higher values of plug grade were obtained in substrates with medium levels of DP and LP, and medium-to-low proportions of Pe. The predicted values for DWs were higher in substrates with high proportions of Pe (Figure 1).

Significant correlations were found between all chemical or physical properties of the substrates and the final plug plant characteristics (Table V). High values of macro-nutrient contents and $\mathrm{BD}$ were negatively correlated with root and crown DWs, respectively. In contrast, high macro-nutrient contents and BD values were positively correlated with leaf DW, in agreement with the well-known antagonistic relationship between root and leaf development. However, no significant correlations were found between plug grade and the physical or chemical properties of the substrate, even though positive correlations were found between organic matter content and water content, and negative correlations between CI and BD or PD (Table V).

Considering plug plant survival and plant DWs, all nine substrates may be considered appropriate for strawberry plug plant production. Nevertheless, according to these results, substrates with medium-tohigh proportions [from $60-70 \%(\mathrm{v} / \mathrm{v})$ ] of LP, and low proportions [from $10-30 \%(\mathrm{v} / \mathrm{v})$ ] of DP and perlite are recommended. These have low nutrient contents, high OM contents, low $\mathrm{pH}$, and low CI values, and are recommended as they lead to higher plug quality, and greater root and crown DWs.

Funding was provided by the Spanish Ministry for Science and Technology-FEDER through Research Project No. AGL2004-04365/AGR. The authors are grateful to Dr. J.L. Guardiola and Dr. Manual Abad for comments on this manuscript. The authors are also grateful to Ms. Debra Westall for revising the grammar of the manuscript.

TABLE V

Correlation coefficients between plant growth parameters and the physical or chemical properties of the nine substrates tested

\begin{tabular}{|c|c|c|c|c|c|c|}
\hline Parameter & Plug grade & Leaf number & Petiole length & Root dry weight & Leaf dry weight & Crown dry weight \\
\hline $\mathrm{pH}$ & 0.14 & -0.35 & -0.64 & 0.48 & $-0.76 *$ & 0.49 \\
\hline $\mathrm{EC}$ & 0.13 & 0.46 & 0.49 & -0.39 & $0.67 *$ & -0.34 \\
\hline Organic matter & 0.41 & 0.32 & 0.27 & -0.29 & 0.24 & 0.19 \\
\hline Coarseness index & -0.31 & -0.17 & -0.24 & 0.27 & -0.22 & -0.04 \\
\hline Bulk density & -0.13 & 0.13 & 0.22 & -0.26 & $0.62 * *$ & $-0.49 * *$ \\
\hline Particle density & -0.35 & -0.16 & -0.18 & 0.23 & -0.19 & -0.10 \\
\hline Total porosity & -0.21 & -0.28 & -0.29 & 0.33 & $-0.58 * *$ & 0.20 \\
\hline Air volume & -0.29 & -0.07 & -0.31 & 0.35 & -0.30 & 0.05 \\
\hline Water volume & 0.30 & 0.05 & 0.31 & -0.34 & 0.27 & -0.04 \\
\hline $\mathrm{N}-\mathrm{NO}_{3}^{-}$ & -0.03 & 0.27 & $0.45 *$ & $-0.42 *$ & $0.45 *$ & -0.07 \\
\hline $\mathrm{H}_{2} \mathrm{PO}_{4}$ & 0.07 & 0.31 & 0.38 & $-0.45 *$ & $0.45 *$ & -0.05 \\
\hline $\mathrm{K}^{+}$ & 0.14 & 0.27 & 0.36 & $-0.40 *$ & $0.40 *$ & -0.08 \\
\hline
\end{tabular}

*,** Significant differences at $P<0.05$ and $P<0.01$, respectively. 


\section{REFERENCES}

Bish, E. B., Cantliffe, D. J. and Chandler, C. K. (2001). A system for producing large quantities of greenhouse-grown strawberry plantlets for plug production. HortTechnology, 11, 636-638.

Bish, E. B., Cantliffe, D. J. and Chandler, C. K. (2002). Temperature conditioning and container size affect early season fruit yield of strawberry plug plants in a winter, annual hill production system. HortScience, 37, 762-764.

Bish, E. B., Cantliffe, D. J. and Chandler, C. K. (2003). Plantlet size affects growth and development of strawberry plug transplants. Proceedings of the Florida State Horticultural Society, 116, 105-107.

Bunt, A. C. (1988). Media and Mixes for Container-Grown Plants. Unwin Hyman, London, UK. 35 pp.

Castillo, J. E. and Arjona, A. (2004). Épocas de plantación de plantas de fresa (Fragaria $\times$ ananassa Duch.). Terralia, 44, 56-61.

Cornell, J. A. (1990). Experiments with Mixtures. Designs, Models, and the Analysis of Mixture Data.2nd Edition. Wiley, New York, USA. 21-98.

Crawford, T. D., Himelrick, D. G., Sibley, J. L. and Pitts, J. (2000). Effect of runner plantlet size on performance of strawberry plug plants. Small Fruits Review, 1, 15-21.

Durner, E. F., Poling, E. B. and MaAs, J. L. (2002). Recent advances in strawberry plug transplant technology. HortTechnology, 12, 545-550.

EN 13037 - EUROPEAN STANDARDS (2001). Determination of pH. Soil Improvers and Growing Media. European Committee for Standardisation (CEN), Brussels, Belgium. 11 pp.

EN 13038 - EUROPEAN STANDARDS (2001). Determination of Electrical Conductivity. Soil Improvers and Growing Media. European Committee for Standardisation (CEN), Brussels, Belgium. 13 pp.

EN 13039 - EUROPEAN STANDARDS (2001). Determination of Organic Matter Content and Ash. Soil Improvers and Growing Media. European Committee for Standardisation (CEN), Brussels, Belgium. 11 pp.

EN 13040 - EUROPEAN STANDARDS (2001). Sample Preparation for Chemical and Physical Tests, Determination of Dry Matter Content, Moisture Content and Laboratory Compacted Bulk Density. Soil Improvers and Growing Media. European Committee for Standardisation (CEN), Brussels, Belgium. 18 pp.

EN 13041 - EUROPEAN STANDARDS (2001). Determination of Physical Properties. Dry Bulk Density, Air Volume, Water Volume, Shrinkage Value and Total Pore Space. Soil Improvers and Growing Media. European Committee for Standardisation (CEN), Brussels, Belgium. 19 pp.

Hochmuth, G., Cantliffe, D., Chandler, C., Stanley, C., Bish, E., Waldo, E., Legard, D. and Duval, J. (2006). Fruiting responses and economics of containerized and bare-root strawberry transplants established with different irrigation methods. HortTechnology, 16, 205-210.
KoKALIS-BurELlE, N. (2003). Effects of transplant type, plant growth-promoting rhizobacteria, and soil treatment on growth and yield of strawberry in Florida. Plant and Soil, 256, 273-280.

LIETEN, F. (1998). Recent advances in strawberry plug transplant technology. Acta Horticulturae, 513, 383-388.

Maher, M., Prasad, M. and Raviv, M. (2008). Organic soilless media components. In: Soilless Culture: Theory and Practice. (Raviv, M. and Lieth, J. H., Eds.). Elsevier, Amsterdam, The Netherlands. 459-504.

Mohamed, F. H. (1998). Current and future usage of micropropagated strawberry plug transplants in Egypt. Acta Horticulturae, 513, 389-392.

Palha, M. G. S., Andrade, M. C. S. and Silva, M. J. P. (2002). The effects of different types of plant production on strawberry yield and fruit quality. Acta Horticulturae, 567, 515-518.

Paranjpe, A. Cantliffe, D. J., Lamb, E. M. Stofella, P. J. and Powell, C. (2003). Increasing winter strawberry production in North-Central Florida using ventilated greenhouses and high plant densities. Acta Horticulturae, 626, 269-276.

Paranjpe, A., Cantliffe, D. J. and Koenig, R. L. (2004). Developing a system to produce organic plug transplants for organic strawberry production. Proceedings of the Florida State Horticultural Society, 117, 276-282.

Poling, E. B. and PARKer, K. (1990). Plug production of strawberry transplants. Advances in Strawberry Production, 9, 37-39.

Raigón, M. D., Pérez-García, M., Maguieira, A. and Puchades, R. (1992). Determination of available nitrogen (nitric and ammoniacal) in soils by flow injection analysis. Analysis, 20, 483-487.

Raviv, M., Wallach, R., Silber, A. and Bar-Tal, A. (2002). Substrates and their analysis. In: Hydroponic Production of Vegetables and Ornamentals. (Savvas, D. and Passam, H., Eds.). Embryo Publications, Athens, Greece. 25-101.

Richards, D., LANE, M. and BEARDSELl, D. V. (1986). The influence of particle-size distribution in pinebark:sand:brown coal potting mixes on water supply, aeration and plant growth. Scientia Horticulturae, 29, 1-14.

RobBe, A. (2004). Multiplication hors sol du fraisier: des plants de meilleure qualite. Le Fruit Belge, 511, 158-161.

TAKedA, F. and HoKanson, S. C. (2002). Effects of transplant conditioning on 'Chandler' strawberry performance in a winter greenhouse production system. In: Strawberry Research to 2001. (Hokanson, S. C. and Jamieson, R., Eds.). Proceedings of the 5th North American Strawberry Conference. ASHA Press, Alexandria, VA, USA. 132-135.

TAKedA, F., Hokanson, S. C. and Enns, J. M. (2004). Influence of daughter plant weight and position on strawberry transplants production and field performance in annual plasticulture. HortScience, 39, 1592-1595.

Von Post, L. (1937). The geographical survey of Irish bogs. Irish Naturalists Journal, 6, 210-227. 